\title{
COMMENT
}

\section{Recent trends in Pediatric Hematology Oncology fellowship match and the workforce impact}

Scott Moerdler $\mathbb{I D}^{1,2}$ and Scott C. Borinstein ${ }^{3}$

Pediatric Research (2022) 91:492-493; https://doi.org/10.1038/s41390-021-01505-7

In the manuscript authored by Macy et al., global trends of the pediatric subspecialty workforce are described by reporting the numbers of applicants entering fellowship training from 2001 to 2018. ${ }^{1}$ They conclude there has been an increase in the number of physicians entering pediatric subspecialty training. We would like to highlight discrepant changes in accrual into Pediatric Hematology Oncology (PHO) fellowship training, compared to other subspecialties (Table 1). Among the larger fellowship programs, Macy et al. reported
$\mathrm{PHO}$ to have a marked increase in the number of individuals entering fellowship 2008-2018. However, in the recent PHO fellowship matches there has been a significant and consistent decrease in total applicants. The 2021 fellow match resulted in an $8 \%$ decrease in applications and left nearly half (44\%) of PHO fellowship programs unfilled (Table 2). Across the country, PHO programs have been scrambling to fill these unoccupied positions. More broadly, fellowship program directors and division chiefs are trying to understand

Table 1. National Resident Matching Program (NRMP) pediatric subspecialty fellow match results 2018-2021. ${ }^{4}$

\begin{tabular}{|c|c|c|c|c|c|c|c|c|c|c|c|c|c|}
\hline \multirow[t]{2}{*}{ Specialty } & \multirow[t]{2}{*}{ Salary ${ }^{a}$} & \multicolumn{3}{|l|}{2021} & \multicolumn{3}{|l|}{2020} & \multicolumn{3}{|l|}{2019} & \multicolumn{3}{|l|}{2018} \\
\hline & & $\begin{array}{l}\text { Total } \\
\text { applicants }\end{array}$ & $\begin{array}{l}\% \\
\text { Positions } \\
\text { filled }\end{array}$ & $\begin{array}{l}\text { Unfilled } \\
\text { programs }\end{array}$ & $\begin{array}{l}\text { Total } \\
\text { applicants }\end{array}$ & $\begin{array}{l}\% \\
\text { Positions } \\
\text { filled }\end{array}$ & $\begin{array}{l}\text { Unfilled } \\
\text { programs }\end{array}$ & $\begin{array}{l}\text { Total } \\
\text { applicants }\end{array}$ & $\begin{array}{l}\% \\
\text { Positions } \\
\text { filled }\end{array}$ & $\begin{array}{l}\text { Unfilled } \\
\text { programs }\end{array}$ & $\begin{array}{l}\text { Total } \\
\text { applicants }\end{array}$ & $\begin{array}{l}\% \\
\text { Positions } \\
\text { filled }\end{array}$ & $\begin{array}{l}\text { Unfilled } \\
\text { programs }\end{array}$ \\
\hline $\begin{array}{l}\text { Neonatal-Perinatal } \\
\text { Medicine }\end{array}$ & 0.99 & 267 & 93 & 16 & 240 & 87.2 & 25 & 245 & 86.7 & 25 & 243 & 87.1 & 22 \\
\hline $\begin{array}{l}\text { Pediatric Critical Care } \\
\text { Medicine }\end{array}$ & 1.00 & 233 & 99.5 & 1 & 227 & 98.5 & 3 & 217 & 99 & 2 & 204 & 96.2 & 6 \\
\hline $\begin{array}{l}\text { Pediatric Emergency } \\
\text { Medicine }\end{array}$ & 0.89 & 221 & 100 & 0 & 253 & 98 & 3 & 270 & 100 & 0 & 232 & 98.9 & 2 \\
\hline Pediatric Cardiology & 0.95 & 157 & 94.9 & 6 & 160 & 92.4 & 13 & 177 & 98.1 & 3 & 161 & 96.6 & 4 \\
\hline $\begin{array}{l}\text { Pediatric Hematology } \\
\text { Oncology }\end{array}$ & 0.69 & 133 & 75.6 & 32 & 147 & 82.8 & 22 & 165 & 89.8 & 14 & 163 & 90 & 15 \\
\hline $\begin{array}{l}\text { Pediatric Hospital } \\
\text { Medicine }\end{array}$ & 0.72 & 122 & 98.8 & 1 & 105 & 97.1 & 1 & 79 & 92.9 & 3 & 66 & 96 & 2 \\
\hline $\begin{array}{l}\text { Pediatric } \\
\text { Gastroenterology }\end{array}$ & 0.70 & 118 & 98.2 & 2 & 106 & 95.1 & 5 & 102 & 92.1 & 6 & 100 & 93.3 & 7 \\
\hline $\begin{array}{l}\text { Pediatric } \\
\text { Endocrinology }\end{array}$ & 0.66 & 63 & 60.2 & 32 & 70 & 62 & 34 & 53 & 50.5 & 42 & 65 & 66.7 & 29 \\
\hline $\begin{array}{l}\text { Pediatric } \\
\text { Pulmonology }\end{array}$ & 0.74 & 56 & 68.4 & 23 & 52 & 66.2 & 21 & 43 & 54.1 & 29 & 48 & 68.1 & 21 \\
\hline Pediatric Nephrology & 0.68 & 53 & 73.9 & 16 & 39 & 59.4 & 22 & 27 & 41.5 & 33 & 39 & 62.1 & 19 \\
\hline $\begin{array}{l}\text { Pediatric Infectious } \\
\text { Diseases }\end{array}$ & 0.63 & 42 & 54.5 & 30 & 49 & 63 & 23 & 40 & 46.8 & 35 & 45 & 55.6 & 25 \\
\hline $\begin{array}{l}\text { Developmental and } \\
\text { Behavioral Pediatrics }\end{array}$ & NA & 34 & 76.2 & 8 & 26 & 52.2 & 19 & 35 & 62.5 & 15 & 35 & 67.3 & 19 \\
\hline $\begin{array}{l}\text { Pediatric } \\
\text { Rheumatology }\end{array}$ & 0.66 & 28 & 73.5 & 9 & 33 & 69 & 13 & 22 & 48.7 & 15 & 24 & 53.7 & 17 \\
\hline Adolescent Medicine & 0.64 & 26 & 76.7 & 7 & 36 & 96.7 & 1 & 32 & 75 & 7 & 25 & 67.7 & 9 \\
\hline Child Abuse & NA & 19 & 70.8 & 7 & 18 & 54.5 & 10 & 17 & 65 & 7 & 18 & 51.9 & 13 \\
\hline $\begin{array}{l}\text { Academic General } \\
\text { Pediatrics }\end{array}$ & 0.70 & 7 & 50 & 7 & 12 & 52.6 & 9 & 10 & 50 & 8 & - & - & - \\
\hline
\end{tabular}

NA data not available.

${ }^{a}$ Salary is calculated as the ratio of the highest pediatric subspecialty median salary at the assistant professor rank. ${ }^{5}$

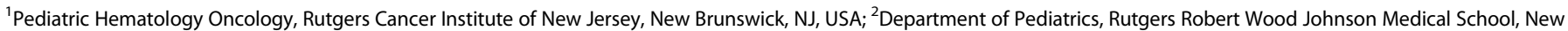
Brunswick, NJ, USA and ${ }^{3}$ Division of Hematology-Oncology, Department of Pediatrics, Vanderbilt University Medical Center, Nashville, TN, USA Correspondence: Scott Moerdler (Scott.moerdler@rutgers.edu)

Received: 10 February 2021 Revised: 19 February 2021 Accepted: 12 March 2021

Published online: 7 April 2021 


\begin{tabular}{|c|c|c|c|c|c|c|c|}
\hline 2009 & 57 & 142 & 144 & 123 & $14(25 \%)$ & 19 (13\%) & 21 (17\%) \\
\hline 2010 & 58 & 146 & 149 & 132 & $10(17 \%)$ & 14 (9.5\%) & 17 (13\%) \\
\hline 2013 & 65 & 164 & 183 & 154 & $8(12 \%)$ & $10(6 \%)$ & 29 (19\%) \\
\hline 2014 & 62 & 157 & 178 & 151 & $6(10 \%)$ & $8(5 \%)$ & 27 (18\%) \\
\hline 2015 & 65 & 162 & 181 & 153 & 7 (11\%) & 9 (5.5\%) & 28 (18\%) \\
\hline 2016 & 67 & 164 & 201 & 159 & $4(6 \%)$ & $5(3 \%)$ & $42(26 \%)$ \\
\hline 2017 & 68 & 166 & 188 & 163 & $3(4 \%)$ & $3(2 \%)$ & $25(15 \%)$ \\
\hline
\end{tabular}

the cause of continued decline in $\mathrm{PHO}$ training interest and its future impact on our workforce.

From 2008 to 2016, PHO fellowship applications steadily rose from 150 applicants to a peak of 201 applicants in 2016. However, in the past 5 years fellow applications have steadily fallen, with only 133 applications in the 2021 match cycle (Table 2). Interestingly, the number of programs and positions has increased consistently during this time, with $72 \mathrm{PHO}$ fellowship programs (representing 176 positions) participating in the 2021 Match. Other pediatric subspecialty programs did not demonstrate the same decline in fellowship applications (Table 1). Herein we try to offer some reasons that may have contributed to these findings.

Macy et al. highlight that one of the most common factors influencing resident career decisions is future job opportunity. We hypothesize that challenges in the $\mathrm{PHO}$ workforce may be contributing to the decrease in PHO fellow applications. The job market has been perceived by graduating fellows to be more competitive in the past several years. Fellows often report few job prospects upon graduation in "desirable" practices or geographical locations. Alternatively, they choose to continue training in a subspecialty fellowship to augment their research portfolio and increase clinical expertise in a particular niche, such as neurooncology, hemostasis, or stem cell transplant, with the hopes of "becoming more marketable" for highly sought after academic positions. ${ }^{2}$ We worry that this additional training, along with a perception of a paucity of faculty positions in PHO, is negatively influencing resident subspecialty decisions.

The PHO provider workforce is also changing, which may be impacting employment opportunities for fellow graduates. Hord et al. reported that from 2012 to 2015 PHO practices employed more advanced practice practitioners, who perform some of the roles of a PHO physician and may decrease the number of faculty positions in a given practice. ${ }^{3}$

Additionally, subspecialty compensation may also contribute to the decrease in PHO fellow applications. According to the American Association of Medical Colleges 2019-20 Faculty Salary Report, Pediatric Critical Care has the highest median salary at the assistant professor level of any pediatric subspecialty, approximately $\$ 250,000$ per year. Fields with higher median salaries tend to have the most applicants and the highest percentages of filled fellowship spots compared to those with lower median compensation (Table 1). Pediatric residents choosing a subspecialty likely are incorporating future wage potential into their career decisions, which may contribute to increased interest in higher paying pediatric specialties.
Recently, we have witnessed additional external factors impacting training programs. In 2018, restrictive US immigration and travel policies were implemented, which may have influenced international clinicians applying and entering US fellowship programs. During this time period, we have seen a decline in the number of $\mathrm{PHO}$ international applications. The coronavirus disease 2019 pandemic has also had a devastating economic impact on academic medical centers and has resulted in an employment freeze in many markets, thus limiting PHO faculty positions for graduates. The pandemic likely has also contributed to the decrease in fellowship applications in 2020 as pediatric residents have deferred future career decisions to remain closer to home and family until quarantine and social distancing measures abate. We certainly hope that we see a rebound of pediatric residents with an interest in a career in $\mathrm{PHO}$, but it is essential to be aware of the changing landscape of our specialty. Further investigation is warranted into how these factors are affecting career decision making of pediatric residents to better understand fellowship applications as well as pediatric subspecialty workforce overall.

\section{ADDITIONAL INFORMATION}

Competing interests: S.C.B. serves on the advisory board for Ipsen Pharmaceuticals and Fennec Pharmaceuticals.

Consent statement: No consent was required for this commentary.

Publisher's note Springer Nature remains neutral with regard to jurisdictional claims in published maps and institutional affiliations.

\section{REFERENCES}

1. Macy, M. L., Leslie, L. K., Turner, A. \& Freed, G. L. Growth and changes in the pediatric medical subspecialty workforce pipeline. Pediatr. Res. https://doi.org/ 10.1038/s41390-020-01311-7 (2020).

2. Leavey, P. J. et al. The American Society of Pediatric Hematology/Oncology workforce assessment: Part 2-Implications for fellowship training. Pediatr. Blood Cancer 65, e26765 (2018).

3. Hord, J. et al. The American Society of Pediatric Hematology/Oncology workforce assessment: Part 1-Current state of the workforce. Pediatr Blood Cancer 65, e26780 (2018).

4. NRMP. National Residency Matching Program. www.nrmp.org (2021).

5. AAMC. AAMC Faculty Salary Report, 2019-20. www.aamc.org (2021). 